RUHUNA JOURNAL OF SCIENCE

Vol 11 (2): 157-165, December 2020

eISSN: $2536-8400$

Short paper

\title{
Ethnobotanical study of Buru Community Forest, Taraba State, Nigeria
}

\author{
Aderopo Akinsoji ${ }^{1}$, Doris Omoigui ${ }^{2}$, Lanre Ogunyebi $* 3$ \\ ${ }^{1}$ Department of Botany, University of Lagos, Lagos, Nigeria \\ ${ }^{2}$ Department of Botany and Biotechnology, University of Benin, Benin, Nigeria \\ ${ }^{3}$ Department of Cell Biology and Genetics, University of Lagos, Nigeria \\ *Correspondence: logunyebi@ unilag.edu.ng; (i) ORCID: https://orcid.org/0000-0003-2315-470X
}

Received: $18^{\text {th }}$ June 2019, Revised: 08 ${ }^{\text {th }}$ June 2020, Accepted: $29^{\text {th }}$ November 2020

\begin{abstract}
An ethnobotanical study of Buru Community Forest was conducted using Participatory Rural Appraisal techniques. A total of 91 species of plants belonging to 43 Families with high endemicity were recorded. The dominant families were Fabaceae, Euphorbiaceae, and Meliaceae. Many species such as Tetrapleura tetrapetra, Phyllanthus mullerianus, Sarcocephalus latifolius and Aframomum melegueta had multiple uses. The three major uses of the species are for medicinal (39 species), edible (33 species) and construction purposes (30 species).
\end{abstract}

Keywords: Buru community forest, Ethnobotanical, Participatory Rural Appraisal technique.

\section{Introduction}

Buru is a small, remote rural village in Kurmi Local Government Area of Taraba State, Nigeria. The village is at the edge of a lowland rainforest called Buru Community Forest (BCF). Buru has six other associated hamlets which collectively form Buru community (Obot and Inahoro 2004). By a Participatory Forest Management arrangement with Taraba State Forestry Department, Buru Community Forest is being maintained and managed by the Buru community.

$\mathrm{BCF}$ is located between $6^{0} 5^{\prime}$ to $7^{0} 05^{\prime} \mathrm{N}$ and $10^{\circ} 81^{\prime}$ to $10^{\circ} 96^{\prime} \mathrm{E}$ (Figure 1 ) at an altitude of 314 asl in the foothills of Mambilla highlands and covers an area of 10,800 hectares (Akinsoji 2013). The area faces the rain-laden wind from the Atlantic coast (Chapman and Chapman 2010) with a mean annual rainfall of $290 \mathrm{~mm}$ (Bawdwen and Tuley 1969) with bimodal peaks in July and September (Akinsoji 2013). The dry season runs between November and March with a brief spell of dry 
and cold harmattan wind in December (Akinsoji 2013). BCF is a fragmented part of the Guinea Forest biodiversity hotspot which extends from Sierra Leone to Congo, and it is known to be one of the 36 biodiversity hotspots of global significance for conservation priorities (Myers et al. 2002, Noss 2016). It is rich in biodiversity and it has been designated as an important birding area (Ezealor 2002). The soil is of volcanic origin comprising various ratios of clay mixture hence the ground is characterized by hills and depressions which make the terrain hilly and rugged (Obot and Inahoro 2004). The forest is a lowland rain forest with characteristic vertical stratification and dense canopy coverage draped with lianas and climbers. The forest harbours some endangered species and many IUCN red data list plants. The common forest species include Khaya grandifoliola, Milicia excelsa, Terminalia superba, Ceiba pentandra, Cola gigantea, Bosqueia angolensis, Khaya ivorensis, Entandrophragma utile, Tetrapleura tetrapetra and Zanthoxylum zanthoxyloides. Buru community is an agrarian community, and the main occupation is farming. Over the years, parcels of the forest had experienced structural changes. For instance, the traditional slash and burn followed by shifting cultivation had turned some of the farmed forest parcels into derived savanna. Some common species of the derived savanna include Hymenocardia acida, Anogeissus lieocarpus, Uapaca togoensis, Terminalia avicennioides, T. laxiflora, Combretum spp., Crossopteryx febrifuga, Sarcocephalus latifolius and Detarium microcarpum.

Buru is a small settlement of about 600 people dominated by the Tigun ethnic group who are the land-owners (Akinsoji 2013). The others are Ndoros, Kakas, and Mambillas who are migrant farmers. They have lived and survived in this environment for generations with minimal contact with the rest of the world depending only on forest resources to meet their livelihood needs. The major components of the resources are plants. This study was carried out to document how the people use plants for their survival.

\section{Material and Methods}

The survey was carried out using Participatory Rural Appraisal (PRA) techniques (Martin 1995, McCracken et al. 1998, Akinsoji 2003). Focus Group Discussions were conducted in Buru and the satellite hamlets. At each site, three groups comprising men, women and youths were engaged in discussions. Two teachers from Buru primary school acted as interpreters. In addition, one-on-one interviews were also held with certain individuals who were passive during the group discussions. Quantitative data collected for Buru and the hamlets were similar, so they were pooled. The validity of information gathered was verified by triangulation (Walter 1998, Akinsoji 2003). The data compiled was further discussed with the participants. Plant specimens were identified and recorded. Those that could not be immediately identified were recorded with their indigenous (Hausa) names. Their botanical 
nomenclature was deciphered using Gbile (1980). Those whose Hausa names were not known were taken to Forestry Herbarium in Ibadan where they were identified and confirmed. All the plant specimens in healthy condition were then deposited in Gashaka Herbarium located in Gashaka Gumti National Park.

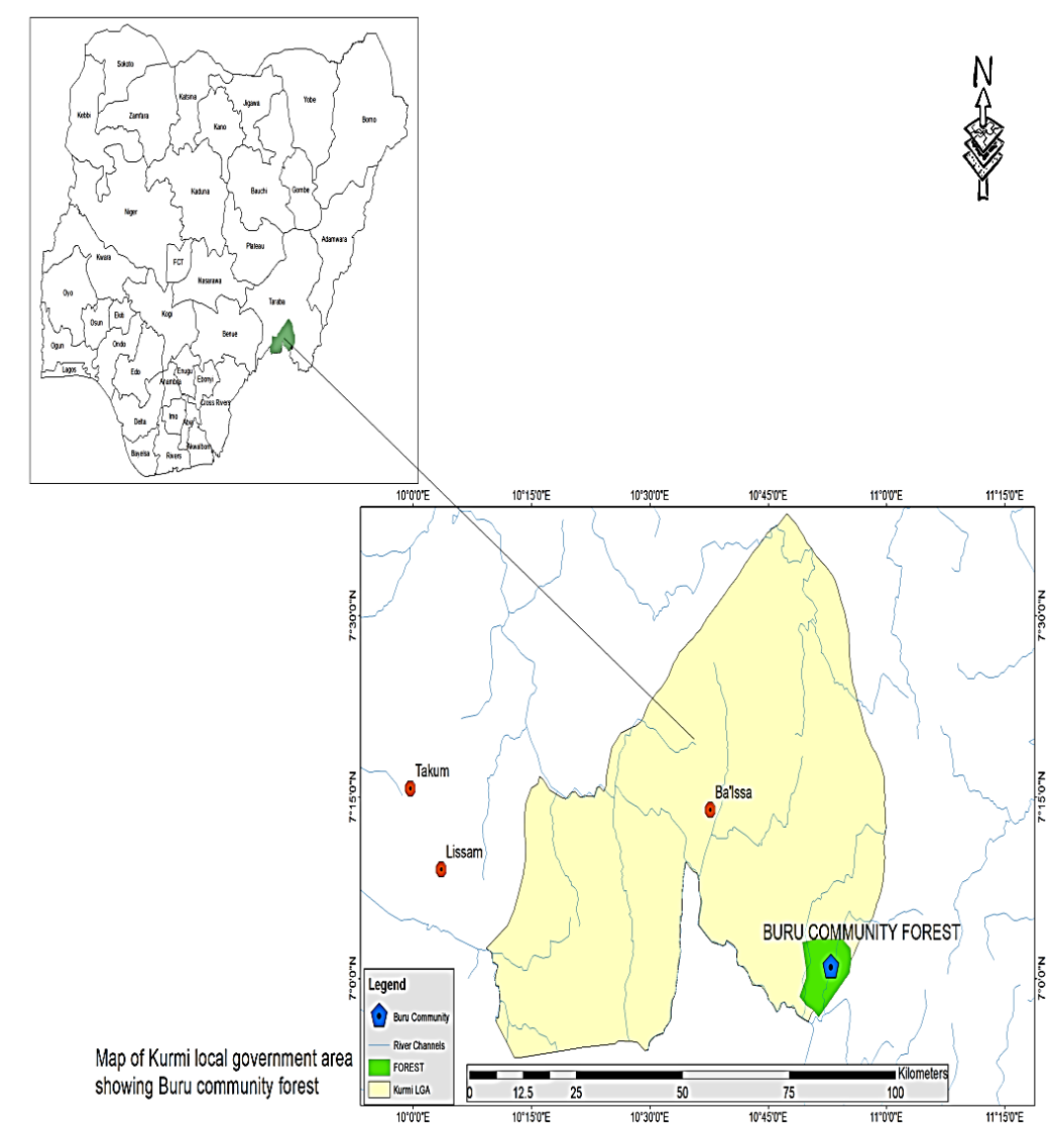

Fig.1: Map of Nigeria showing Buru community forest

\section{Results and Discussion}

A total of 91 species of plants belonging to 43 families were sampled in Buru community forest (BCF), and interestingly they were reported as endemic to this community. The family Fabaceae dominated with 14 species. The families Euphorbiaceae and Meliaceae had six species each while the Families Apocynaceae and Rubiaceae had five species each. The above five families constituted more than 
one-third of all species encountered. Some species such as Tetrapluera tetrapetra and Aframomum melegueta are used for more than one purpose. T. tetrapetra plant is used to treat skin rash and chest pain, while the edible fruit is added to pepper soup for flavor. It is also burnt to give an aroma which is believed to drive away evil spirits. Such multiple purpose plants have been recorded in Gashaka Gumti National Park, Nigeria (Akinsoji 2003), Malawi (Maghembe and Seyani 1991) and in Phillipines (Rondolo 2000). The major uses for plants are medicinal, edible and construction purposes.

\subsection{Medicinal plants}

Thirty-nine species belonging to 23 families of medicinal plants were recorded in the Buru Community Forest (BCF). The two Families Fabaceae and Euphorbiaceae dominated with five species each while the Family Apocynaceae had four species. The remaining Families had one or two species each (Table 1). The part of plants that is mostly used for medicinal purpose is the leaf. This is probably due to its function as the site of production of biological molecules that have bioactive properties. Similar findings were also reported by Anbarashan and Padmavathy (2010) in India and Phannel et al. (2010) in Western Kenya. Nineteen (48.7\%) species had their leaves used for treating ailments. Five species had their fruits used for medicinal purposes, while four species had their roots, and four species had their seeds respectively. Three species, Tetrapleura tetrapetra, Anselia gigantea and Crinum jagus are used for magical/mythical purposes. T. tetrapetra fruit is used to drive away evil spirits, A. gigantea is used as a love charm while $C$. jagus is used as a protective charm. This corroborates Walker (1999) claim that some aspects of traditional medicine are linked with magic.

Table 1: Medicinal plants of Buru Community Forest

\begin{tabular}{llll}
\hline Species & Family & Part Used & Uses \\
& & & \\
\hline Acanthus montanus (Nees) T. Anders & Acanthaceae & Leaf & Typhoid \\
Alchornea cordifolia (Schum \&Thonn.) Mull.Arg. & Euphorbiaceae & Leaf & Malaria \\
Ansellia gigantea Rchb F. & Orchidaceae & Pseudobulb Love Charm \\
Cenchrus aralioides Roxb. & Poaceae & Dried Plant Impotence \\
Chromolaena odorata (Linn.) King \& Robinson & Asteraceae & Leaf & Wound Dressing \\
Cissus aralioides (Welw.Ex Bak.) Planch & Ampelidaceae & Root & Dizziness \\
Celtis ferruginea DC. & Connaraceae & Fruit & Oral Hygiene \\
Commelina sp Linn. & Commelinaceae & Leaf & Wound treatment \\
Costus dubius (Afzel.) K. Schum & Costaceae & Leaf & Cough, Mouth \\
& & & Sores \\
Crinum jagum (Themps.) Dandy & Amaryllidaceae & Leaf & Protective Charm \\
Culcasia scandens P. Beauv & Araceae & Leaf & Purgative \\
Erythrina vogelli Hook. F. & Fabaceae & Leaf & Malaria \\
Euphorbia hirta Linn. & Euphorbiaceae & Leaf & Skin Disease \\
\hline
\end{tabular}


Table 1. Continued

\begin{tabular}{|c|c|c|c|}
\hline Species & Family & Part Used & Uses \\
\hline Garcinia kola Heckel & Guttiferae & Seed & Cough \\
\hline Ixora brachypoda DC. & Rubiaceae & Sap & Wound Dressing \\
\hline Jatropha podagrica Hook. & Euphorbiaceae & Leaf & Wound Treatment \\
\hline Kigelia Africana (Lam.) Benth & Bignoniaceae & Bark & Body Pains \\
\hline Lophira alata Banks ex.Gaertn.F & Ochnaceae & Leaf & Heart Pain \\
\hline Macaranga barteri Muell. Arg. & Euphorbiaceae & & \\
\hline Napoleona imperialis P.Beauv. & Lecythidaceae & Root & Fever \\
\hline Olax subscorpioidea Oliv. & Olacaceae & Stem Sap & Antiseptic \\
\hline Phyllanthus mullerianus (Kuntze) Ex. & Euphorbiaceae & Leaf & Malaria \\
\hline Piper guineense Schum \& Thonn. & Piperaceae & Seed & Skin Rash \\
\hline Piper umbellatum Linn. & Piperaceae & Seed & Skin Rash \\
\hline Rauvolfia vomitora Afzel. & Apocynaceae & Leaf & Malaria \\
\hline Sarcocephalus latifolius (Sm.) Bruce & Rubiaceae & Root & $\begin{array}{l}\text { Gonorrhea, } \\
\text { Stomach Pain }\end{array}$ \\
\hline Senna alata (Linn.) Roxb. & Fabaceae & Leaf & Skin Diseases \\
\hline Senna siamea Mill. & Fabaceae & Flower & $\begin{array}{l}\text { Activate } \\
\text { Lactation }\end{array}$ \\
\hline Solanum torvum $\mathrm{Sw}$ & Solanaceae & Leaf & Rib Pain \\
\hline Solenostemon monostachyus P. Beauv. & Lamiaceae & & \\
\hline Stereospermum kunthianum Cham. & Bignoniaceae & Bark & $\begin{array}{l}\text { Dysentery/ } \\
\text { Stomachache }\end{array}$ \\
\hline Strombosia pustulata Oliv. & Olacaceae & & \\
\hline Strophanthus hispidus DC. & Apocynaceae & Leaf & Navel Pain \\
\hline Tabernaemontana pachysiphon Stapf. & Apocynaceae & Fruit & STD \\
\hline Tamarindus indica Linn. & Fabaceae & Fruit & Aphrodisiac \\
\hline Tetrapleura tetrapetra (Schum\&Thonn) Taub. & Fabaceae & Seed & $\begin{array}{l}\text { Chest Pain, Skin } \\
\text { Rash }\end{array}$ \\
\hline Vernonia amygdalina Dcl. & Asteraceae & Leaf & $\begin{array}{l}\text { Fever, General } \\
\text { Tonic }\end{array}$ \\
\hline Voacanga Africana Stapf. & Apocynaceae & Fruit & STD \\
\hline Xylopia aethiopica (Dunal) A.Rich. & Annonaceae & Fruit & Skin Rash \\
\hline $\begin{array}{l}\text { Zanthoxylum zanthoxyloides (Lam) Zepern.\& } \\
\text { Timler }\end{array}$ & Rutaceae & Root & Sickle Cell \\
\hline
\end{tabular}

\subsection{Edible plants}

Thirty-three species of edible plants belonging to 23 Families were recorded in BFC (Table 2). The family Fabaceae dominated with 6 species while the other species had one or two species each. Twenty-five of the species were trees. The most common edible part was the fruit (19 species) which are known to be source of nutrients and vitamins hence they are good food supplements. The other edible plants were seed (10 species) and leaf ( 7 species). The seeds are used as spices to add flavour and aroma to foods/ soups while the leaves are eaten as vegetables as well as spices. Some of these have been reported to be sold in Lagos markets (Akinsoji 2017). Hence, Lagos and some other towns could be potential outlets for these plants to 
serve as a source of supplementary family income for Buru inhabitants. Elaies guineensis is remarkable because at least three of its parts are edible. Its palm oil is used for frying and making of stews, the kernel oil is edible and used in making soap while the sap is taken as palm wine. These edible plants are important in the rural economy by increasing household income for the family as they are harvested and taken to markets for sale. Akinsoji (2003) and Campbell (1987) made similar observations in Gashaka (Nigeria) and Zimbabwe, respectively.

Table 2: Edible plants of Buru Community Forest

\begin{tabular}{|c|c|c|c|c|c|}
\hline Species & Family & Leaf & Fruit & Seed & Tuber \\
\hline Aframomum melegueta $\mathrm{K}$. Schum & Zingiberaceae & & & + & \\
\hline Annona senegalensis Pers. & Annonaceae & & + & & \\
\hline Beilschmiedia manni (Meisn.) Benth.\& Thonn.F. & Lauraceae & & + & & \\
\hline Blighia sapida Konig & Sapindaceae & & + & & \\
\hline Brachystegia eurycoma Harms & Fabaceae & & & + & \\
\hline Chrysophyllum albidum G.Don & Sapotaceae & & + & & \\
\hline Crassocephalum rubens (Juss. Ex. Jacq.) S. Moore & Asteraceae & & + & & \\
\hline Diallium guineense Wild. & Fabaceae & & + & & \\
\hline Dacryodes edulis (G. Don) HJ. Lam & Burseraceae & & + & & \\
\hline Elaeis guinensis Jacq. & Arecaceae & & + & + & + \\
\hline $\begin{array}{l}\text { Irvingia gabonensis Aubry- Leconte ex O } \\
\text { Rorke) Baill }\end{array}$ & Irvingiaceae & & + & + & \\
\hline Kigelia Africana (Lam.) Benth & Bignoniaceae & & & & + \\
\hline Landolphia owariensis P. Beauv. & Apocynaceae & & + & & \\
\hline Maesobotrya dusenii (Pax) Hutch & Euphorbiaceae & & + & & \\
\hline Mangifera indica Linn. & Anacardiaceae & & + & & \\
\hline Moringa oleifera Lam. & Moringaceae & + & + & + & \\
\hline Musanga cecropioides Muell. Arg & Moraceae & + & & & \\
\hline Napoloena imperialis P.Beauv. & Lecythidaceae & & + & & \\
\hline Ocimum gratissimum Linn. & Labiatae & + & & & \\
\hline Parkia biglobosa Jacq Benth & Fabaceae & & + & + & \\
\hline Persea Americana Mill. & Lauraceae & & + & & \\
\hline Piper guineense Schum. \&Thonn. & Piperaceae & & & + & \\
\hline Piper umbellatum Linn. & Piperaceae & & & + & \\
\hline Psidium guajava Linn. & Myrtaceae & & + & & \\
\hline Pterocarpus erinaceus Poir & Fabaceae & + & & & \\
\hline Ricinodendron heudelotii (Baill.) Pierre & Euphorbiaceae & & & + & \\
\hline Tamarindus indica Linn. & Fabaceae & & + & & \\
\hline Tetrapleura tetrapetra (Schum. \& Thonn.) Taub. & Fabaceae & & + & & \\
\hline Trichilia preuriana A. Juss & Meliaceae & & + & & \\
\hline Vernonia amygdalina Del. & Asteraceae & + & & & \\
\hline Vitex simplicifolia Oliv. & Verbenaceae & + & & & \\
\hline Xylopia aethiopica (Dunal) A.Rich. & Annonaceae & & + & + & \\
\hline $\begin{array}{l}\text { Zanthoxylum zanthoxyloides (Lam.) Zepernick } \\
\text { \&Timber }\end{array}$ & Rutaceae & & & & + \\
\hline
\end{tabular}




\subsection{Construction plants}

Table 3 shows that thirty species of plants are used for construction purposes. These plants belong to thirteen families dominated by Families Meliaceae, Fabaceae and Poaceae. Seventeen of these are timber species while the remaining thirteen are either soft wooded trees (2) or herbaceous species belonging to the Family Poaceae (e.g. Phragmites and Palisota). Timber species are used mainly for house construction (roofing, doors and furniture) while the soft wooded species are used for making agricultural implements such as hoe or knife, and cutlass handles. Grasses are used mainly to thatch roofs of huts but some are also used to make baskets, mats, door curtains and chairs which can be sold in markets to support family income. Akinsoji (2003) reported similar results for Gashaka Gumti National Park. Entada barks are stripped and used as ropes to tie wooden beams together in thatching roofs with grasses. The timber species are conserved through a joint management agreement with Taraba State Forestry Department. The agreement vests the ownership and management of BCC on Buru community and does not permit commercial logging. Only community members can log for personal building purposes and permission to $\log$ must be obtained from Forest Management Committee of the community.

Table 3: Construction plants of Buru Community Forest, Nigeria

\begin{tabular}{|c|c|c|c|}
\hline Species & Family & $\begin{array}{l}\text { Parts } \\
\text { used }\end{array}$ & Use \\
\hline \multicolumn{4}{|l|}{ a) Timber } \\
\hline Afzelia Africana $\mathrm{Sm}$. & Fabaceae & $\begin{array}{l}\text { Wood } \\
\text { (hard) }\end{array}$ & $\begin{array}{l}\text { Roofing of buildings, } \\
\text { furniture, wooden } \\
\text { houses etc, }\end{array}$ \\
\hline Albizia zygia (DC.) J.F. Macbr. & Fabaceae & + & + \\
\hline Aubrevillea kerstingii (Harms) Pellegr. & Fabaceae & + & + \\
\hline \multicolumn{4}{|l|}{ Brachystegia eurycoma Harms } \\
\hline Canarium schwenfurthii Linn. & Burseraceae & + & + \\
\hline Celtis zenkeri Engl. & Meliaceae & + & + \\
\hline Diospyros dendo Welw.Ex.Hein & Ebenaceae & & \\
\hline Funtumia africana & Apocynaceae & & \\
\hline Hallea ciliate Aubr.\& Pellegr. & Rubiaceae & + & + \\
\hline Khaya ivorensis C. DC. & Meliaceae & + & + \\
\hline Khaya grandifoliola C. DC. & Meliaceae & + & + \\
\hline Khaya senegalensis (Desr.) A.Juss & Meliaceae & + & + \\
\hline Lovoa trichidioides Harms. & Meliaceae & + & + \\
\hline Milicia excelsa (Nelw.) C.C. Bery & Moraceae & + & + \\
\hline Piptadeniastrum africanum (Hook. F.) Brenan & Fabaceae & + & + \\
\hline Sterculia rhinopetala K. Schum & Sterculiaceae & + & + \\
\hline Trilepisium madagascariense DC & Moraceae & + & + \\
\hline
\end{tabular}


Table 3 continued.

\begin{tabular}{|c|c|c|c|}
\hline & Family & Parts used & Use \\
\hline \multicolumn{4}{|l|}{ b) Non-timber species } \\
\hline Borassus aethiopum Mert. & Arecaceae & $\begin{array}{l}\text { Stem and } \\
\text { frond }\end{array}$ & $\begin{array}{l}\text { Roof beams and } \\
\text { thatching }\end{array}$ \\
\hline Elaeis guineensis Jacq. & Arecaceae & frond & $\begin{array}{l}\text { Making baskets and } \\
\text { furniture }\end{array}$ \\
\hline Entada purseantha DC. & Fabaceae & bark & $\begin{array}{l}\text { Rope for tying roof } \\
\text { beams }\end{array}$ \\
\hline Kigelia Africana (Lam.) Benth & Bignoniaceae & soft wood & $\begin{array}{l}\text { Making wooden } \\
\text { handles for knives } \\
\text { and agricultural } \\
\text { implements }\end{array}$ \\
\hline $\begin{array}{l}\text { Laccosperma secundiflorum (P.Beaux) O } \\
\text { Kuntze }\end{array}$ & Arecaceae & culm & Cane furniture \\
\hline Oxytenanthera abyssinica (A. Rich,) Munro & Poaceae & stem & $\begin{array}{l}\text { Making huts, fences } \\
\text { and furniture }\end{array}$ \\
\hline Pandanus crassicaulis Huynh & Pandanaceae & leaves & Thatching/roofing \\
\hline Palisota hirsuta (Thunb.) K. Schum & Poaceae & whole plant & Thatching of huts \\
\hline Panicum maximum Jacq. & Poaceae & culm & Thatching \\
\hline Phragmites karka (Retz,) Trin. Ex.steud). & Poaceae & culm & $\begin{array}{l}\text { Beds, chairs and } \\
\text { thatching }\end{array}$ \\
\hline Rothmania hispida (K.Schum) & Rubiaceae & soft wood & $\begin{array}{l}\text { Wooden handles for } \\
\text { knives and } \\
\text { agricultural } \\
\text { implements (e.g. hoe) }\end{array}$ \\
\hline Vitex simplicifolia Stapf & Verbenaceae & soft wood & $\begin{array}{l}\text { Wooden handles for } \\
\text { knives and agricultural } \\
\text { implements (e.g. Hoe) }\end{array}$ \\
\hline
\end{tabular}

\section{Conclusions}

The study documents how the people in the Buru community in Kurmi Local Government Area use plants for their survival. It revealed high abundance of plant resources in this area and how traditional farming system of slash and burn impacted on the plant resources, though the management option of Buru Community Forest as a result of the agreement between the Taraba State Forestry Department and the community help in adequate protection and sustainability of the forest. This study recommends that inhabitants should be educated on the importance of conservation as continuous exploitation of the plant resouces without adequate conservation strategies can lead to loss of some of these important plant resources. 


\section{Acknowledgements}

We thank Mr. Emma Hamzat, the Divisional Forest Officer for granting us the permission to carry out the study and introducing us to Buru Community. We are grateful to Chief Joel Emma and the Buru community for their hospitality and cooperation. Mr. Emmah Lucas and Mrs. Mercy M. Luka served as interpreters gratis. Anonymous reviewers of RJS are acknowledged.

\section{References}

Akinsoji A. 2003. Vegetation studies of Gashaka Gumti National Park, Nigeria 1: Ethnobotany. The Nigerian Field 68:124-144

Akinsoji A. 2013. Community-Based Forest Management in Buru, Taraba State, Nigeria. Journal of Environment and Earth Science 3(12): 146-151

Akinsoji A. 2017. Market survey of Spices and vegetables obtained from four markets in Lagos metropolis. FUW Trends in Science and Technology 2(2): 788-791

Anbarashan M, Padmavathy A. 2010. Ethno-medicinal plants of five sacred groves in Andalore District, Tamilnadu, India. Ethnobotanical Leaflets 14: 774-780

Bawden MG, Tuley P. 1969. The land resources of S. Sardauna and S. Adamawa Provinces, Northern Nigeria. Land Resources Division, Tolworth, Surrey.

Chapman JD, Chapman HM. 2001. The forests of Taraba and Adamawa States, Nigeria. An ecological account and plant species checklist. University of Canterbury, Christchurch, New Zealand.

Ezealor AU. 2002. Critical sites for Biodiversity Conservation in Nigeria. Nigerian Conservation Foundation, Lagos. 110pp.

Gbile ZO. 1980. Vernacular names of Nigerian plants (Hausa). Federal Department of Forestry, Lagos. $63 \mathrm{pp}$.

Martin GJ. 1995. Ethnobotany. Chapman and Hall, London. 268pp

McCracken JA, Preety JN, Conway GR. 1998. An Introduction to rapid rural appraisal for agricultural development. Internationl Institute for Environment and Development, London.

Myers N, Mittermeier CG, de Fonseca GAB, Kent J. 2002. Biodiversity hotspots for priorities. Nature 403: 1045

Noss R. 2016. Announcing the World's 36th Biodiversity Hotspot: The North American Coastal Plain. Retrieved on 08/16/2020, https://www.cepf.net/stories/announcing-worlds-36th-biodiversity-hotspotnorth-american-coastal-plain

Obot EA, Inahoro I. 2004. Natural Resources Management Plan for Buru community forest. Nigerian Conservation Foundation, Lagos. 58pp.

Phannel AS, Nyunja RO, Onyago JC. 2010. Plant species in the folk medicine of Kit Mikayi region, Western Kenya. Ethnobotanical Leaflets 10: 836-840

Walter S. 1998. The utilization of non-timber forest products in the rainforest of Madagascar. A case study. Plants Research and Development 48: 121-144 